\title{
Urban Air Pollution Modeling
}

\author{
Anjali Srivastava and B. Padma S. Rao \\ National Environmental Engineering Research Institute, \\ Kolkata Zonal Centre \\ India
}

\section{Introduction}

All life form on this planet depends on clean air. Air quality not only affects human health but also components of environment such as water, soil, and forests, which are the vital resources for human development.

Urbanization is a process of relative growth in a country's urban population accompanied by an even faster increase in the economic, political, and cultural importance of cities relative to rural areas. Urbanization is the integral part of economic development. It brings in its wake number of challenges like increase in population of urban settlement, high population density, increase in industrial activities (medium and small scale within the urban limits and large scale in the vicinity), high rise buildings and increased vehicular movement. All these activities contribute to air pollution. The shape of a city and the land use distribution determine the location of emission sources and the pattern of urban traffic, affecting urban air quality (World Bank Reports 2002). The dispersion and distribution of air pollutants and thus the major factor affecting urban air quality are geographical setting, climatological and meteorological factors, city planning and design and human activities.

Cities in the developing countries are characterized by old city and new development. The old cities have higher population density, narrow lanes and fortified structures.

In order to ensure clean air in urban settlements urban planning and urban air quality management play an important role. New legislations, public awareness, growth of urban areas, increases in power consumption and traffic pose continuous challenges to urban air quality management. UNEP (2005) has identified niche areas Urban planning need to primarily focus on as:

- Promotion of efficient provision of urban infrastructure and allocation of land use, thereby contributing to economic growth,

- managing spatial extension while minimizing infrastructure costs,

- improving and maintaining the quality of the urban environment and

- $\quad$ Prerecording the natural environment immediately outside the urban area.

Air quality modelling provides a useful support to decision making processes incorporating environmental policies and management process. They generate information that can be used in the decision making process. The main objectives of models are: to integrate observations, to predict the response of the system to the future changes, to make provision for future development without compromising with quality 


\section{Urban air quality}

The urban air is a complex mixture of toxic gases and particulates, the major source is combustion of fossil fuels.Emissions from fossil fuel combustion are reactive and govern local atmospheric chemistry.Urban air pollution thus in turn affect global troposphere chemistry and climate (e.g. tropospheric $\mathrm{O}_{3}$ and $\mathrm{NO}_{x}$ budgets, radiative forcing by $\mathrm{O}_{3}$ and aerosols). Sources of air pollutants in urban area, their effect and area of concern are summarized in Table 1.

\begin{tabular}{|c|c|c|c|}
\hline Source & Pollutants & Effects & Area of concern \\
\hline $\begin{array}{l}\text { Large number of } \\
\text { vehicles }\end{array}$ & \multirow{12}{*}{$\begin{array}{c}\text { Particulate matters } \\
\left(\mathrm{PM}_{10}, \mathrm{PM}_{2.5}\right) \text {, Lead } \\
(\mathrm{Pb}), \text { Sulphur dioxide } \\
\left(\mathrm{SO}_{2}\right), \text { Oxides of } \\
\text { nitrogen }\left(\mathrm{NO}_{x}\right) \text {, Ozone } \\
\left(\mathrm{O}_{3}\right), \text { Hydro carbons } \\
\text { (HCs), Carbon } \\
\text { monoxide (CO), } \\
\text { Hydrogen fluoride } \\
\text { (HF), Heavy metals } \\
\text { (e.g. Pb, Hg, Cd etc.) }\end{array}$} & \multirow{3}{*}{$\begin{array}{l}\text { Human Health } \\
\text { (acute and } \\
\text { chronic) }\end{array}$} & \multirow{3}{*}{$\begin{array}{l}\text { Local, Regional } \\
\text { and Global }\end{array}$} \\
\hline $\begin{array}{l}\text { Use of diesel powered } \\
\text { vehicle in large number }\end{array}$ & & & \\
\hline $\begin{array}{l}\text { Use of obsolete vehicles } \\
\text { in large number }\end{array}$ & & & \\
\hline $\begin{array}{l}\text { Large number of motor } \\
\text { cycles/three wheelers ( } 2 \\
\text { stroke and three stroke) }\end{array}$ & & \multirow{3}{*}{$\begin{array}{c}\text { Ecosystem } \\
\text { (acute and } \\
\text { chronic) }\end{array}$} & \multirow{3}{*}{$\begin{array}{l}\text { Local, Regional } \\
\text { and Global }\end{array}$} \\
\hline $\begin{array}{c}\text { Unpaved and/or poorly } \\
\text { maintained street }\end{array}$ & & & \\
\hline Open burning & & & \\
\hline $\begin{array}{l}\text { Inadequate } \\
\text { infrastructure }\end{array}$ & & \multirow{3}{*}{$\begin{array}{l}\text { Greenhouse } \\
\text { gas emission }\end{array}$} & \multirow{3}{*}{ Global } \\
\hline $\begin{array}{l}\text { Low quality of fuel/fuel } \\
\text { adulteration }\end{array}$ & & & \\
\hline $\begin{array}{l}\text { Little emission control \& } \\
\text { technology in industry }\end{array}$ & & & \\
\hline $\begin{array}{l}\text { Presence of industries } \\
\text { (e.g. ceramic, brick } \\
\text { works, agrochemical } \\
\text { factory) }\end{array}$ & & Acid rain & Global \\
\hline Waste incineration & & $\begin{array}{l}\text { Stratospheric } \\
\text { ozone } \\
\text { depletion }\end{array}$ & Global \\
\hline $\begin{array}{l}\text { Limited dry deposition } \\
\text { of pollutants }\end{array}$ & & $\begin{array}{l}\text { Long-range } \\
\text { transport }\end{array}$ & Global \\
\hline
\end{tabular}

Table 1. Urban sources of air pollutants, their effect and area of concern.

Urban air pollution involves physical and chemical process ranging over a wide scale of time and space. The urban scale modeling systems should consider variations of local scale 
effects, for example, the influence of buildings and obstacles, downwash phenomena and plume rise, together with chemical transformation and deposition. Atmospheric boundary layer, over 10 to $30 \mathrm{~km}$ distances, governs the dispersion of pollutants from near ground level sources. Vehicular emissions are one the major pollution source in urban areas. Ultrafine particles are formed at the tailpipe due to mixing process between exhaust gas and the atmosphere. Processes at urban scale provide momentum sink, heat and pollutant source thereby influencing the larger regional scale (up to $200 \mathrm{~km}$ ). Typical domain lengths for different scale models is given in table 2.

\begin{tabular}{|c|c|c|c|}
\hline Model & $\begin{array}{c}\text { Typical Domain } \\
\text { Scale }\end{array}$ & $\begin{array}{l}\text { Typical } \\
\text { resolution }\end{array}$ & Motion Example \\
\hline Micro scale & $200 \times 200 \times 100 \mathrm{~m}$ & $5 \mathrm{~m}$ & $\begin{array}{l}\text { Molecular diffusion, } \\
\text { Molecular viscosity }\end{array}$ \\
\hline $\begin{array}{l}\text { Mesoscale } \\
\text { (urban) }\end{array}$ & $100 \times 100 \times 5 \mathrm{~km}$ & $2 \mathrm{~km}$ & $\begin{array}{l}\text { Eddies, small plumes, car } \\
\text { exhaust, cumulus clouds }\end{array}$ \\
\hline Regional & $1000 \times 1000 \times 10 \mathrm{~km}$ & $36 \mathrm{~km}$ & $\begin{array}{c}\text { Gravity waves, } \\
\text { thunderstorms, tornados, } \\
\text { cloud clusters, local winds, } \\
\text { urban air pollution }\end{array}$ \\
\hline $\begin{array}{c}\text { Synoptic } \\
\text { (continental) }\end{array}$ & $3000 \times 3000 \times 20 \mathrm{~km}$ & $80 \mathrm{~km}$ & $\begin{array}{l}\text { High and low pressure } \\
\text { system, weather fronts, } \\
\text { tropical storms, Hurricanes } \\
\text { Antarctic ozone hole, }\end{array}$ \\
\hline Global & $65000 \times 65000 \times 20 \mathrm{~km}$ & $4^{\circ} \times 5^{\circ}$ & $\begin{array}{l}\text { Global wind speed, rossby } \\
\text { (planetary) waves } \\
\text { stratospheric ozone } \\
\text { reduction Global worming }\end{array}$ \\
\hline
\end{tabular}

Table 2. Typical domain length for different scale model

Piringer et al., 2007, have demonstrated that atmospheric flow and microclimate are influenced by urban features, and they enhance atmospheric turbulence, and modify turbulent transport, dispersion, and deposition of atmospheric pollutants. Any urban scale modeling systems should consider effects of the various local scales, for example, the influence of buildings and obstacles, downwash phenomena and plume rise, chemical transformation and deposition. The modelling systems also require information on emissions from various sources including urban mobile pollution sources. Simple dispersion air quality pollution transport models and complex numerical simulation model require wind, turbulence profiles, surface heat flux and mixing height as inputs. In urban areas mixing height is mainly influenced by the structure heights and construction materials, in terms of heat flux. Oke $(1987,1988,1994)$, Tennekes (1973), Garrat $(1978,1980)$, Raupach et al (1980) and Rotach $(1993,1995)$ divided the Atmospheric Boundary Layer within the urban structures into four sub layers (Figure 1). 


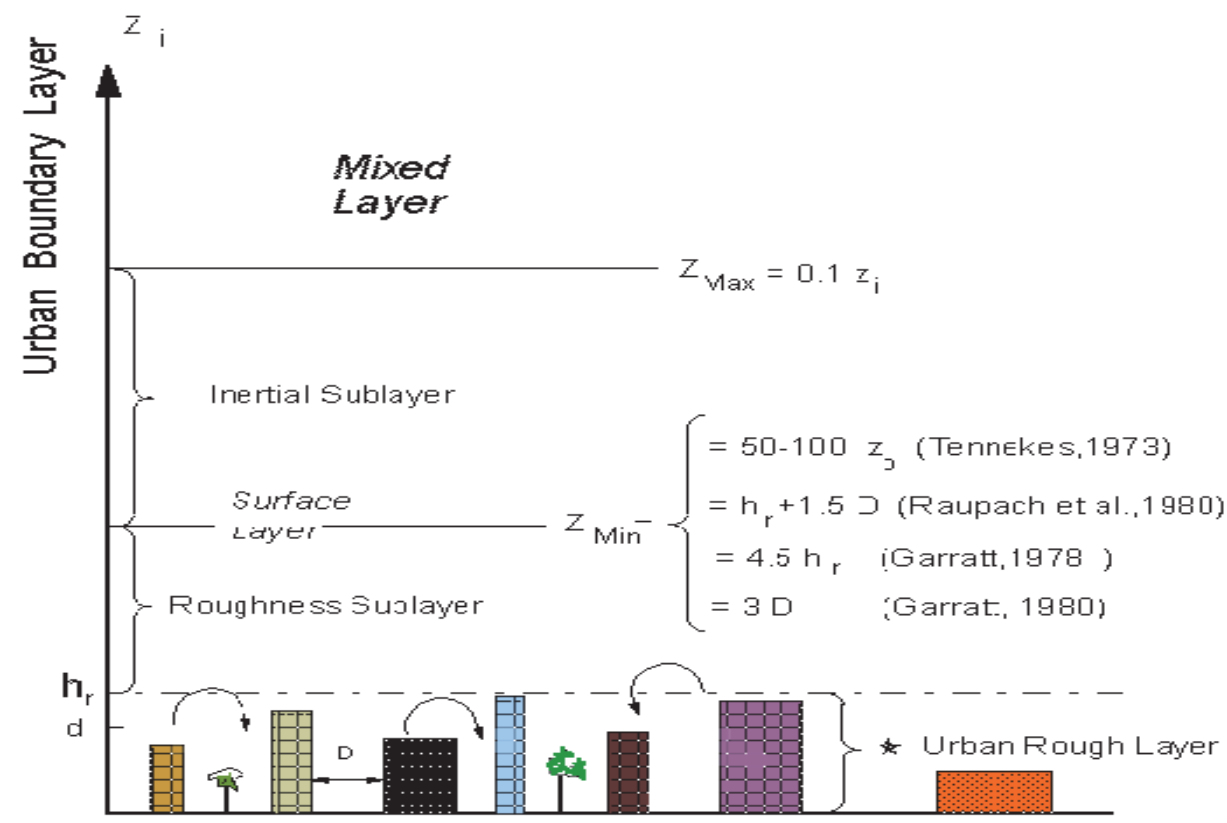

Fig. 1. Boundary- layer structure over a rough urban built- up area A daytime situation is displayed where Z I denotes the mixed layer height. Modefied after Oke (1988) and Rotach (1993).

In urban establishments anthropogenic activities take place between the top of highest building and the ground. People also live in this area. The layer of atmosphere in this volume is termed as Urban Canopy. The thermal exchanges and presence of structures in urban canopy modify the air flows significantly and this makes the atmospheric circulations in urban canopy highly complex. The heterogeneity of urban canopies poses a challenge for air quality modeling in urban areas. The importance of various parameters in different models for urban atmosphere study is given in Table 3. Figure 2 shows the flow and scale lengths within an urban boundary layer, UBL.

\begin{tabular}{|c|c|c|c|}
\hline Parameter & Air Quality & Urban Climatology & Urban Planning \\
\hline Wind speed & Very important & Important & Very Important \\
\hline Wind Direction & Very important & Important & Very Important \\
\hline $\begin{array}{c}\text { Temperature } \\
\text { Humidity }\end{array}$ & Important & Extremely important & Very Important \\
\hline $\begin{array}{c}\text { Pollutant } \\
\text { Concentration }\end{array}$ & $\begin{array}{c}\text { Extremely } \\
\text { important }\end{array}$ & Very important & Very important \\
\hline Turbulent Fluxes & Very important & Very important & Very important \\
\hline
\end{tabular}

Table 3. Ranking of parameters in different applications for urban air environment 


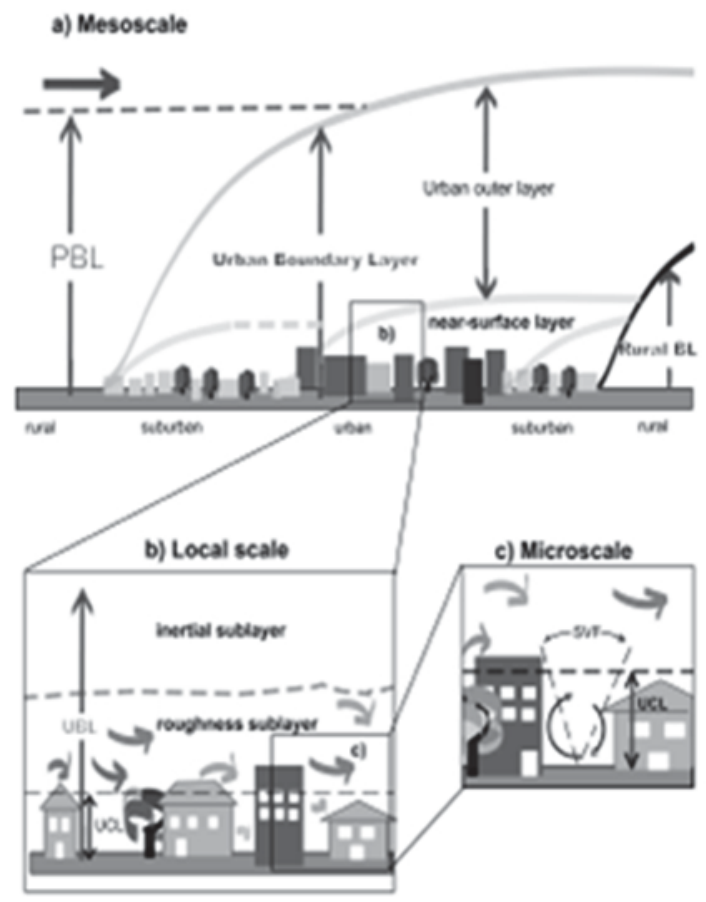

Fig. 2. Schematic diagram showing processes, flow and scale lengths within an urban boundary layer, UBL. This is set in the context of the planetary boundary layer, PBL, the urban canopy layer, UCL, and the sky view factor, SVF, a measure of the degree to which the sky is obscured by surrounding buildings at a given point which characterises the geometry of the urban canopy. Ref:. Meteorology applied to urban pollution problems-Final report COST Action 715. Dementra Ltd Publishers

Vehicles are one of the important pollution sources in urban areas. Maximum exposure to local public is from this source and thus they form important receptor group. Pollutant dispersion of vehicular pollution is at street scale and is the smallest scale in urban environment. Hosker (1985) showed that flows in street canyon are like recirculating eddy driven by the wind flow at the top with a shear layer which separates the above canyon flows from those within it. In deep street canyons the primary vortex does not extend to the ground but a weak contra rotating vortex is formed near the ground and is relatively shallow (Figure 3). Pavageau et al (2001) demonstrated that wind directions which are not normal to the street axis cause variations in the flow. The real geometry of the street canyon and the mean flow and turbulence generated by vehicles within the canyon also affect the recirculating flow.

Concentrations of pollutants at a receptor are governed by advection, dispersion and deposition. Air pollutants can be divided into two main categories namely conventional air pollutants and Hazardous Air Pollutants (HAPs). Conventional air pollutants include particulate matters, sulphur dioxide, nitrogen dioxide, carbon monoxide, particles, lead and the secondary pollutant ozone. HAPs include Volatile Organic Compounds, toxic metals 


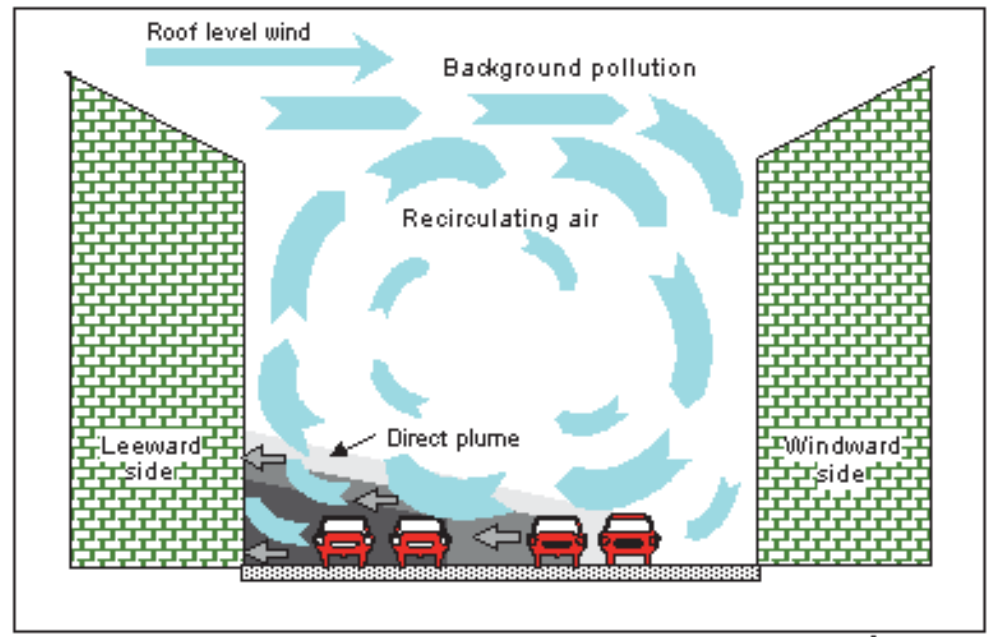

Fig. 3. Air flow pattern in a Street Canyon

and biological agents of many types. All pollutants are not emitted in significant quantities. Secondary pollutants like some VOCs, carbonyls and ozone are formed due to chemical transformation in air. These reactions are often photochemical.

The important components of air quality modelling are thus,

- Knowledge of sources and emissions

- Transport, diffusion and parametrisation

- Chemical transformations

- Removal process

- Meteorology

Understanding contribution from various sources to air quality is the key for effective management of the air quality. Air quality models offer a useful tool in comprehending these issues. These models evaluate the relationship between air pollutant emissions and their resulting concentration in the ambient air. Commonly used air quality models are: 1) Conceptual Models 2) Emission Models 3) Meteorological Models, 4) Chemical Models, 5) Source Oriented Models and 6) Receptor Models.

\section{Air quality model classification}

Air quality models cover either separately or together atmospheric phenomena at various temporal and spatial scales. Urban air models generally focus from local (micro- tens of meters to tens of kilometers) to regional (meso) scale. Models can be broadly divided into two types namely physical and mathematical.

Physical models involve reproducing urban area in the wind tunnel. Scale reduction in the replica and producing scaling down actual flows of atmospheric motion result in limited utility of such models. Moreover these are economically undesirable.

Mathematical models use either use statistics to analyse the available data or mathematical representation of all the process of concern. The second type of mathematical models is constrained by the ability to represent physical and chemical processes in equations without assumptions. 
Statistical model are simple but they do not explicitly describe causal relationships and they cannot be extrapolated beyond limits of data used in their derivation. Thus dependence on past data becomes their major weakness. These cannot be used for planning as they cannot predict effect of changes in emissions.

\subsection{Eulerian and lagrangian models}

Eulerian approach has been used to predict air pollutant concentrations in urban areas. The space domain (geographical area or air volume), are divided into "small" squares (twodimensional) or volumes (three-dimensional), i.e. grid cells. Thus Eulerian models are sometimes called "grid models". Equidistant grids are normally used in air pollution modeling. Then the spatial derivatives involved in the system of Partial Differential Equations are discretized on the grid chosen. The transport, diffusion, transformation, and deposition of pollutant emissions in each cell are described by a set of mathematical expressions in a fixed coordinate system. Chemical transformations can also be included. Long range transport, air quality over entire air shed, that is, large scale simulations are mostly done using Eulerian models. Reynolds (1973), Shir and Shieh (1974) applied Eulerian model for ozone and for $\mathrm{SO}_{2}$ concentration simulation in urban areas, and Egan (1976) and Carmichael (1979) for regional scale sulfur. Holmes and Morawska (2006) used Eulerian model to calculate the transport and dispersion over long distances. The modeling studies by Reynolds (1973) on the Los Angeles basin formed the basis of the, the well-known Urban Air shed Model-UAM. Examples of Eulerian models are CALGRID model and ARIA Regional model or the Danish Eulerian Hemispheric Model (DEHM).

Lagrangian Model approach is based on calculation of wind trajectories and on the transportation of air parcels along these trajectories. In the source oriented models the trajectories are calculated forward in time from the release of a pollutant-containing air parcel by a source (forward trajectories from a fixed source) until it reaches a receptor site. And in receptor oriented models the trajectories are calculated backward in time from the arrival of an air parcel at a receptor of interest (backward trajectories from a fixed receptor). Numerical treatment of both backward and forward trajectories is the same. The choice of use of either method depends on specific case. As the air parcel moves it receives the emissions from ground sources, chemical transformations, dry and wet depositions take place. If the models provide average time-varying concentration estimates along the box trajectory then Lagrangian box models have been used for photochemical modeling. The major shortcoming of the approach is the assumption that wind speed and direction are constant throughout the Physical Boundary Layer. As compared to the Eulerian box models the Lagrangian box models can save computational cost as they perform computations of chemical and photochemical reactions on a smaller number of moving cells instead of at each fixed grid cell of Eulerian models. Versions of EMEP (European Monitoring and Evaluation Programme) are examples of Lagrangian models. These models assume pollutants to be evenly distributed within the boundary layer and simplified exchange within the troposphere is considered.

\subsection{Box models}

Box models are based on the conservation of mass. The receptor is considered as a box into which pollutants are emitted and undergo chemical and physical processes. Input to the model is simple meteorology. Emissions and the movement of pollutants in and out of the 
box is allowed. The air mass is considered as well mixed and concentrations to be uniform throughout. Advantage of the box model is simple meteorology input and detailed chemical reaction schemes, detailed aerosol dynamics treatment. However, following inputs of the initial conditions a box model simulates the formation of pollutants within the box without providing any information on the local concentrations of the pollutants. Box models are not suitable to model the particle concentrations within a local environment, as it does not provide any information on the local concentrations, where concentrations and particle dynamics are highly influenced by local changes to the wind field and emissions.

\subsection{Receptor models}

Receptor modeling approach is the apportionment of the contribution of each source, or group of sources, to the measured concentrations without considering the dispersion pattern of the pollutants. The starting point of Receptor models is the observed ambient concentrations at receptors and it aims to apportion the observed concentrations among various source types based on the known source profile (i.e. chemical fractions) of source emissions. Mathematically, the receptor model can be generally expressed in terms of the contribution from ' $n$ ' independent sources to ' $p$ ' chemical species in ' $m$ ' samples as follows:

$$
C_{i k}=\sum_{j=1}^{n} a_{i j} f_{j k}
$$

Where $C_{i k}$ is the measured concentration of the $k_{t h}$ species in the $i^{\text {th }}$ sample, $a_{i k}$ is the concentration from the $j^{\text {th }}$ source contributing to the $i^{\text {th }}$ sample, and $f_{j k}$ is the $k^{\text {th }}$ species fraction from the $\mathrm{j}^{\text {th }}$ source. Receptor models can be grouped into Chemical mass balance (CMB), Principal Component Analysis (PCA) or Factor analysis, and Multiple Linear Regression Analysis (MLR) and multivariate receptor models.

The Chemical Mass Balance (CMB) Receptor Model used by Friedlander, 1973 uses the chemical and physical characteristics of gases and particulate at source receptor to both identify the presence of and to quantify source contributions of pollutants measured at the receptor. Hopke $(1973,1985)$ christened this approach as receptor modelling. The CMB model obtains a least square solution to a set of linear equation, expressing each receptor concentration of a chemical species as a linear sum product of source profile species and source contributions. The output to the model consists of the amount contributed by each source type to each chemical species. The model calculates the contribution from each source and uncertainties of those values. CMB model applied to the VOC emissions in the city of Delhi and Mumbai (Figure 4 ) shows that emissions from petrol pumps and vehicles at traffic intersection dominate.

PCA and MLR are statistical models and both PMF and UNMIX are advanced multivariate receptor models that determine the number of sources and their chemical compositions and contributions without source profiles. The data in PMF are weighted by the inverse of the measurement errors for each observation. Factors in PMF are constrained to be nonnegative. PMF incorporates error estimates of the data to solve matrix factorization as a constrained, weighted least-squares problem (Miller et al., 2002; Paatero, 2004).

Geometrical approach is used in UNMIX to identify contributing sources. If the data consist of ' $\mathrm{m}$ ' observations of ' $\mathrm{p}$ ' species, then the data can be plotted in a $\mathrm{p}$-dimensional data space, where the coordinates of a data point are the observed concentrations of the species during a 
sampling period. If $n$ sources exist, the data space can be reduced to a $(n-1)$ dimensional space. An assumption that for each source, some data points termed as edge points exist for which the contribution of the source is not present or small compared to the other sources.
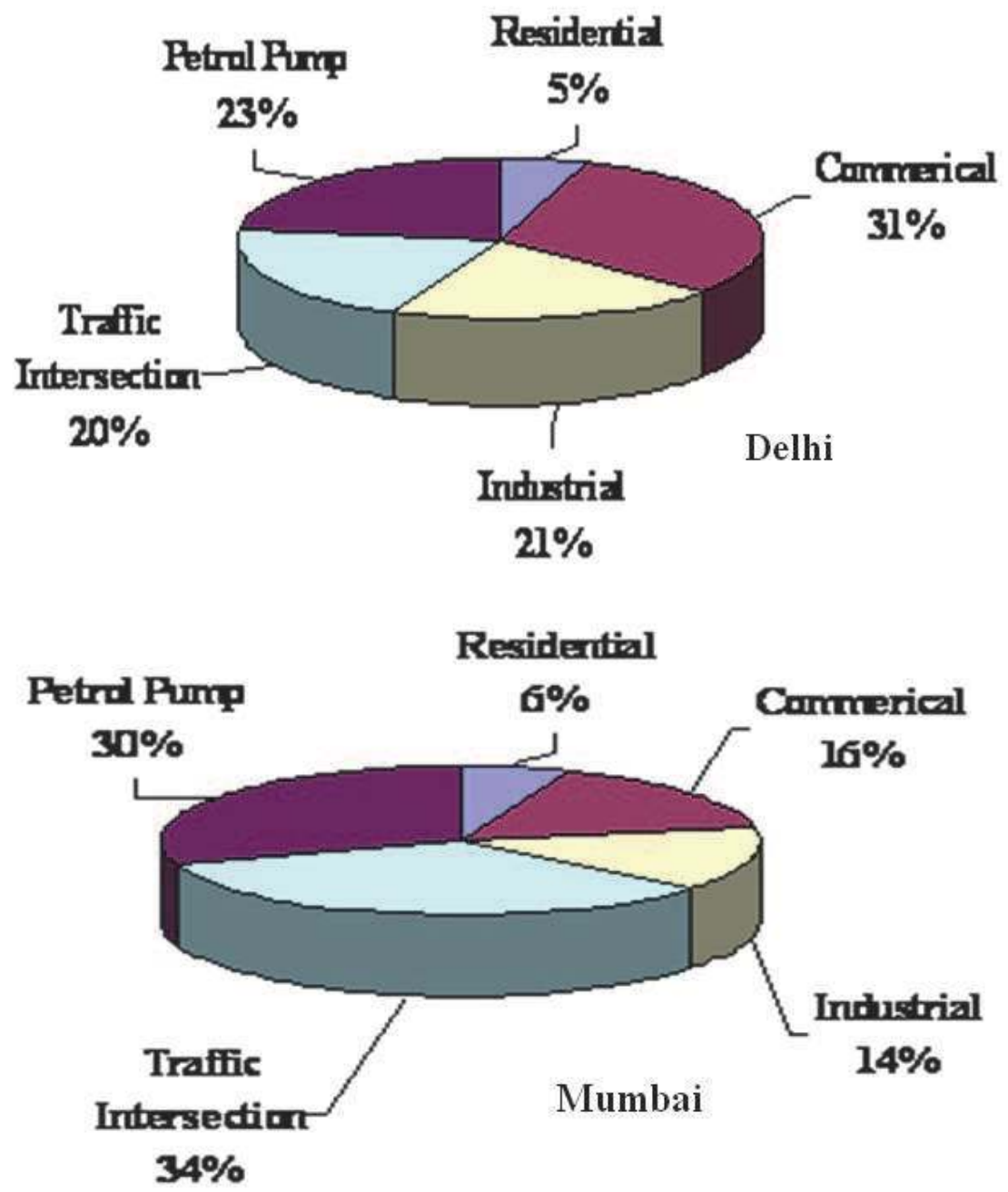

Fig. 4. Category wise Contribution to Total VOCs at Mumbai and Delhi based on CMB results(Ref: Anjali Srivastava 2004, 2005)

UNMIX algorithm identifies these points and fits a hyperplane through them; this hyperplane is called an edge. If $n$ sources exist, then the intersection of $n-1$ of these edges defines a point that has only one contributing source. Thus, this point gives the source composition. In this way, compositions of the $\mathrm{n}$ sources are determined which are used to calculate the source contributions (Henry, 2003). 


\subsection{Computational fluid dynamic models}

Resolving the Navier-Stokes equation using finite difference and finite volume methods in three dimensions provides a solution to conservation of mass and momentum. Computational fluid dynamic (CFD) models use this approach to analyse flows in urban areas. In numerous situation of planning and assessment and for the near-sources region, obstacle-resolved modeling approaches are required. Large Eddy Simulations (LES) models explicitly resolve the largest eddies, and parameterize the effect of the sub grid features. Reynolds Averaged Navier Stokes (RANS) models parameterize all the turbulence, and resolve only the mean motions. CFD (large eddy simulation [LES] or Reynolds-averaged Navier-Stokes [RANS]) model can be used to explicitly resolve the urban infrastructure. Galmarini et al., 2008 and Martilli and Santiago,2008, used CFD models to estimate spatial averages required for Urban Canopy Parameters. Using CFD models good agreement in overall wind flow was reported by field Gidhagen et al. (2004). They also reported large differences in velocities and turbulence levels for identical inputs.

\subsection{The Gaussian steady-state dispersion model}

The Gaussian Plume Model is one of the earliest models still widely used to calculate the maximum ground level impact of plumes and the distance of maximum impact from the source. These models are extensively used to assess the impacts of existing and proposed sources of air pollution on local and urban air quality. An advantage of Gaussian modeling systems is that they can treat a large number of emission sources, dispersion situations, and a receptor grid network, which is sufficiently dense spatially (of the order of tens of meters). Figure 5 shows a buoyant Gaussian air pollutant dispersion plume. The width of the plume is determined by $\sigma_{\mathrm{y}}$ and $\sigma_{\mathrm{z}}$, which are defined by stability classes(Pasquill 1961; Gifford Jr. 1976)

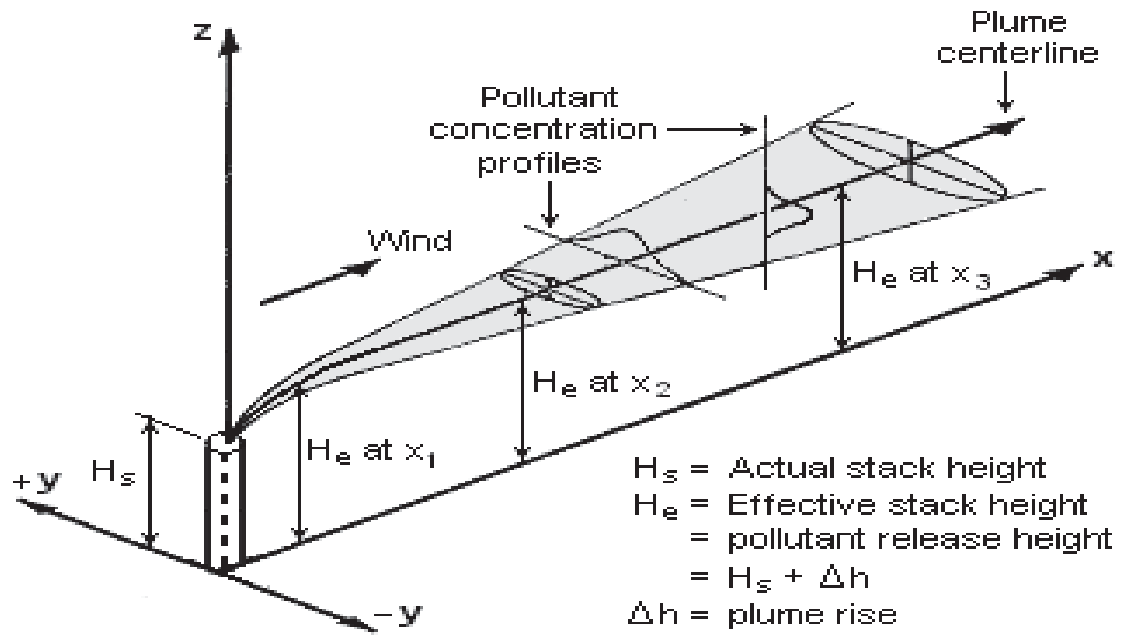

Fig. 5. A buoyant Gaussian air pollutant dispersion plume

The assumptions of basic Gaussian diffusion equations are: 
- that atmospheric stability and all other meteorological parameters are uniform and constant throughout the layer into which the pollutants are discharged, and in particular that wind speed and direction are uniform and constant in the domain;

- that turbulent diffusion is a random activity and therefore the dilution of the pollutant can be described in both horizontal and vertical directions by the Gaussian or normal distribution;

- that the pollutant is released at a height above the ground that is given by the physical stack height and the rise of the plume due to its momentum and buoyancy (together forming the effective stack height);

- $\quad$ that the degree of dilution is inversely proportional to the wind speed;

- that pollutant material reaching the ground level is reflected back into the atmosphere;

- that the pollutant is conservative, i.e., not undergoing any chemical reactions, transformation or decay.

The spatial dynamics of pollution dispersion is described by the following type of equation in a Gaussian model:

$$
\begin{aligned}
C(x, y, z ; H e) & =\frac{Q}{2 \pi u \sigma_{y} \sigma_{z}} \bullet \\
& \bullet\left[\exp \left(-\frac{y^{2}}{2 \sigma_{y}^{2}}\right) \cdot\left\{\exp \left(-\frac{(z-H e)^{2}}{2 \sigma_{z}^{2}}\right)+\exp \left(-\frac{(z+H e)^{2}}{2 \sigma_{z}^{2}}\right)\right\}\right]
\end{aligned}
$$

Where

$\mathrm{C}(\mathrm{x}, \mathrm{y}, \mathrm{z})$ : pollutant concentration at. point $(\mathrm{x}, \mathrm{y}, \mathrm{z})$;

$\mathrm{U}$ : wind speed (in the $\mathrm{x}$ "downwind" direction, $\mathrm{m} / \mathrm{s}$ )

$\Sigma$ : represents the standard deviation of the concentration in the $\mathrm{x}$ and $\mathrm{y}$ direction, i.e., in the wind direction and cross-wind, in meters;

$\mathrm{Q}$ : is the emission strength $(\mathrm{g} / \mathrm{s})$

He: is the effective stack height, see below.

From the above equation, the concentration in any point $(x, y, z)$ in the model domain, from a constant emission rate source, in steady state can be calculated.

Plume rise equations have been developed by Briggs (1975). The effective stack height (physical stack height plus plume rise) depends on exit velocity of gas, stack diameter, average ambient velocity, stack gas temperature and stability of atmosphere

$$
H_{e}=H+\Delta H, \Delta H=1.4 Q_{H}^{1 / 4}\left(\frac{d \theta}{d z}\right)^{-3 / 8}, Q_{H}=\rho Q C_{P}\left(T_{G}-15\right) / 3600
$$

Where

$\mathrm{H}$ : height of stack

$\mathrm{T}_{\mathrm{G}}$ : Temperature of exit gas

Q: Volume of exit gas

$\mathrm{d} \theta / \mathrm{dz}$ : Temperature Gradient

$\rho$ : Density of exit gas

$\mathrm{C}_{\mathrm{P}}$ : Specific heat at constant pressure

Some major air pollution dispersion models in current use 
- $\quad$ ADMS 3: Developed in the United Kingdom (www.cerc.co.uk)

- AERMOD: Developed in the United States, (www.epa.gov/scram001/dispersion_prefrec.htm)

- AUSPLUME: Developed in Australia, (http://www.epa.vic.gov.au/air/epa)

- CALPUFF: Developed in the United States, (www.src.com/calpuff/calpuff1.htm)

- DISPERSION2:Developed in Sweden ,(www.smhi.se/foretag/m/dispersion_eng.htm)

- ISC3: Developed in the United States, (www.epa.gov/ttn/scram/dispersion_alt.htm)

- $\quad$ LADM: Developed in Australia, (Physick, W.L,et al, 1994)

- $\quad$ NAME: Developed in the United

Kingdom,(www.metoffice.gov.uk/research/modelling-systems/dispersion-model)

- MERCURE: Developed in France, (www.edf.com)

- RIMPUFF: Developed in Denmark, (http://www.risoe.dtu.dk)

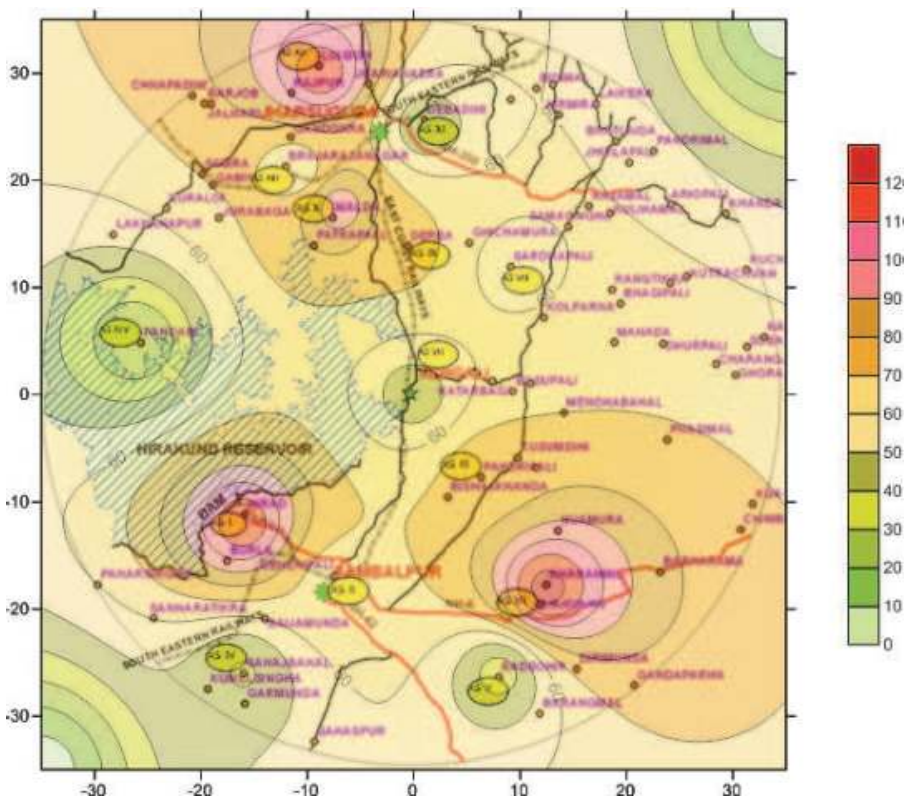

\begin{tabular}{|l|l|}
\hline AQI of ambient air & Description of air quality \\
\hline Below 20 & Excellent \\
\hline Between 20 and 39 & Good \\
\hline Between 40 and 59 & Fair \\
\hline Between 60 and 79 & Poor \\
\hline Between 80 and 99 & Bad \\
\hline Beyond 100 & Dangerous \\
\hline
\end{tabular}

Fig. 6. Air Quality Index of an Industrial Area: Orissa, India

8 regional air quality modeling leading to setting up of air quality index for an industrial area in India is given in Fig 2. This study has resulted in estimating the air assimilative capacity of the region and delineating developmental plans accordingly 


\subsection{Urban pollution and climate integrated modeling}

Integrated air quality modelling systems are tools that help in understanding impacts from aerosols and gas-phase compounds emitted from urban sources on the urban, regional, and global climate. Piringer et al., 2007 have demonstrated that urban features essentially influence atmospheric flow and microclimate, strongly enhance atmospheric turbulence, and modify turbulent transport, dispersion, and deposition of atmospheric pollutants. Numerical weather prediction (NWP) models with increased resolution helps to visualize a more realistic reproduction of urban air flows and air pollution processes.

Integrated models thus link urban air pollution, tropospheric chemistry, and climate. Integration time required is $\geq 10$ years for tropospheric chemistry studies in order to consider $\mathrm{CH}_{4}$ and $\mathrm{O}_{3}$ simulation and aerosol forcing assessment. Tropospheric chemistry and climate interaction studies extend the integration time to $\geq 100$ years.

Urban air quality and population exposure in the context of global to regional to urban transport and climate change is proposed to be assessed by integrating urbanized NWP and Atmospheric Chemistry (ACT) models (Baklanov et al., 2008; Korsholm et al., 2008). A. A. Baklanov and R. B. Nuterman (2009) sugested a multi-scale modelling system which comprised of downscaling from regional to city-scale with the Environment -HIgh Resolution Limited Area Model (Enviro-HIRLAM) and to micro-scale with the obstacleresolved Microscale Model for Urban Environment (M2UE). Meteorology governs the transport and transformations of anthropogenic and biogenic pollutants, drives urban air quality and emergency preparedness models; meteorological and pollution components have complex and combined effects on human health (e.g., hot spots, heat stresses); and pollutants, especially urban aerosols, influence climate forcing and meteorological events (precipitation, thunderstorms, etc.), thus this approach is closer to real life scenario. Examples of integrated models are Enviro-HIRLAM: Baklanov and Korsholm, 2007, WRF-Chem: Grell et al., 2005; EMS-FUMAPEX: Forecasting Urban Meteorology, Air Pollution and Population Exposure; CFD (large eddy simulation [LES] or Reynolds-averaged Navier-Stokes [RANS]) models: Galmarini et al., 2008 and Martilli and Santiago., 2008; MIT Integrated Global System Model Version 2 (IGSM2): A.P. Sokolov, C.A. Schlosser, S. Dutkiewicz, S. Paltsev, D.W. Kicklighter,H.D. Jacoby, R.G. Prinn, C.E. Forest, J. Reilly, C. Wang, B. Felzer,M.C. Sarofim, J. Scott, P.H. Stone, J.M. Melillo and J. Cohen., 2005; US EPA and NCAR communities for MM5 (Dupont et al., 2004; Bornstein et al., 2006; Taha et al., 2008), WRF models (Chen et al., 2006); THOR - an Integrated Air Pollution Forecasting and Scenario Management System: National Environmental Research Institute (NERI), Denmark.

The outline of overall methodology of FUMAPEX and MIT interactive chemistry model is shown in Figure 6 and 7. Schematic of couplings between atmospheric model and the land model components of the MIT IGSM2 is given in Figure 8.

Need of integrated models

All of these models have uncertainties associated with them. Chemical transport models, such as Gaussian plume models and gridded photochemical models, begin with pollutant emissions estimates and meteorological observations and use chemical and physical principles to predict ambient pollutant concentrations. Since these models require temporally and spatially resolved data and can be computationally intensive, they can only be used for well-characterized regions and over select time periods. Eulerian grid models are not suitable to assess individual source impacts, unless the emissions from the individual source are a significant fraction of the domain total emissions. This limitation 


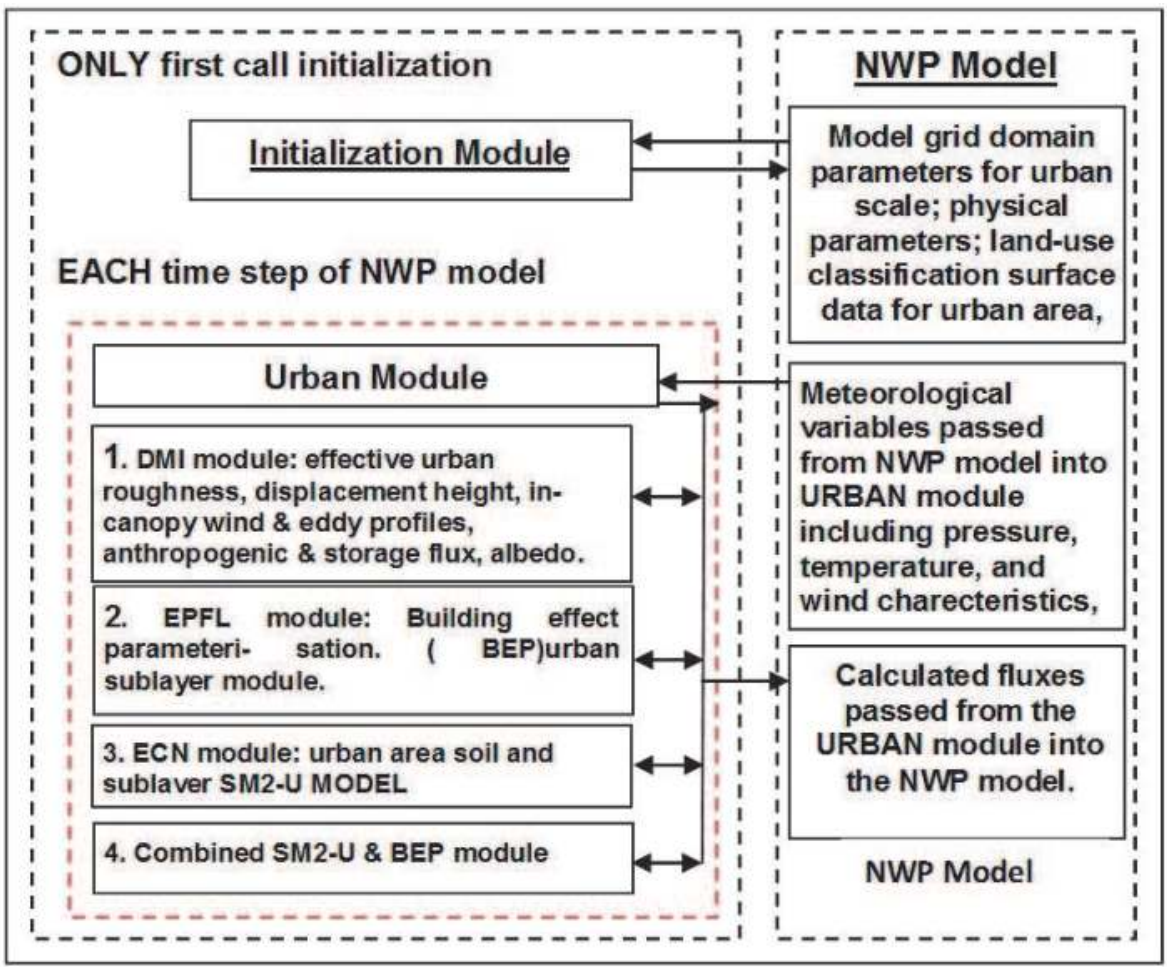

Fig. 7. General scheme of the FUMAPEX urban module for NWP models.

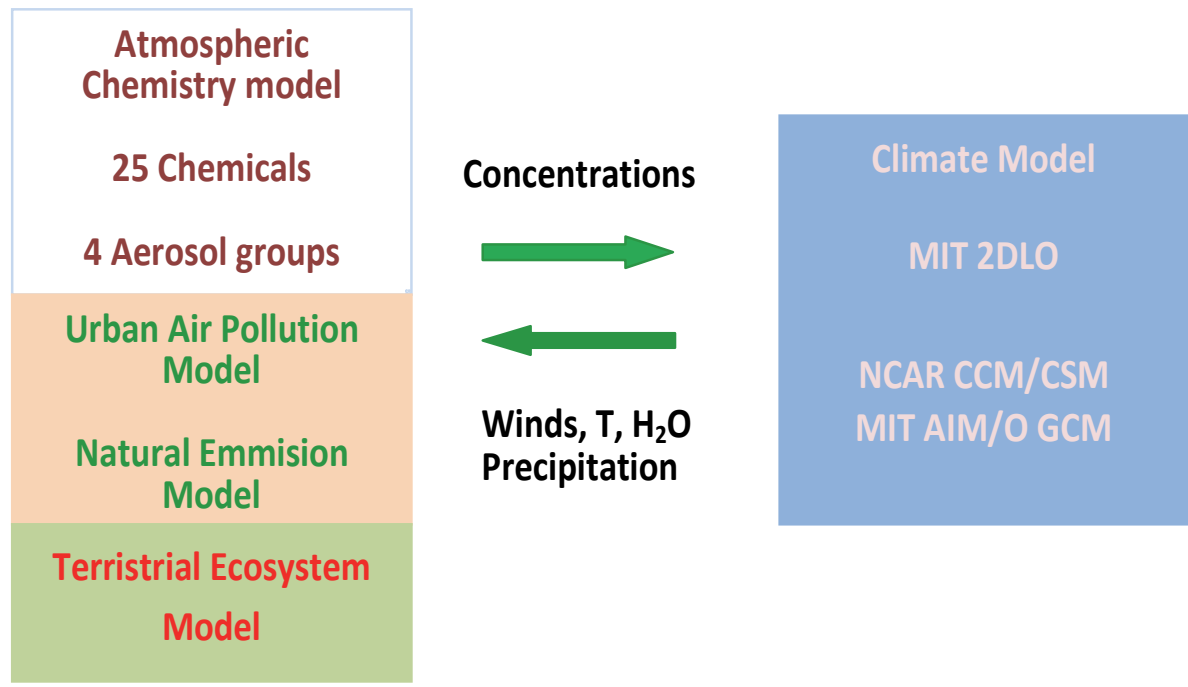

Fig. 8. Overall Scheme MIT Interactive Chemistry-Climate Model 


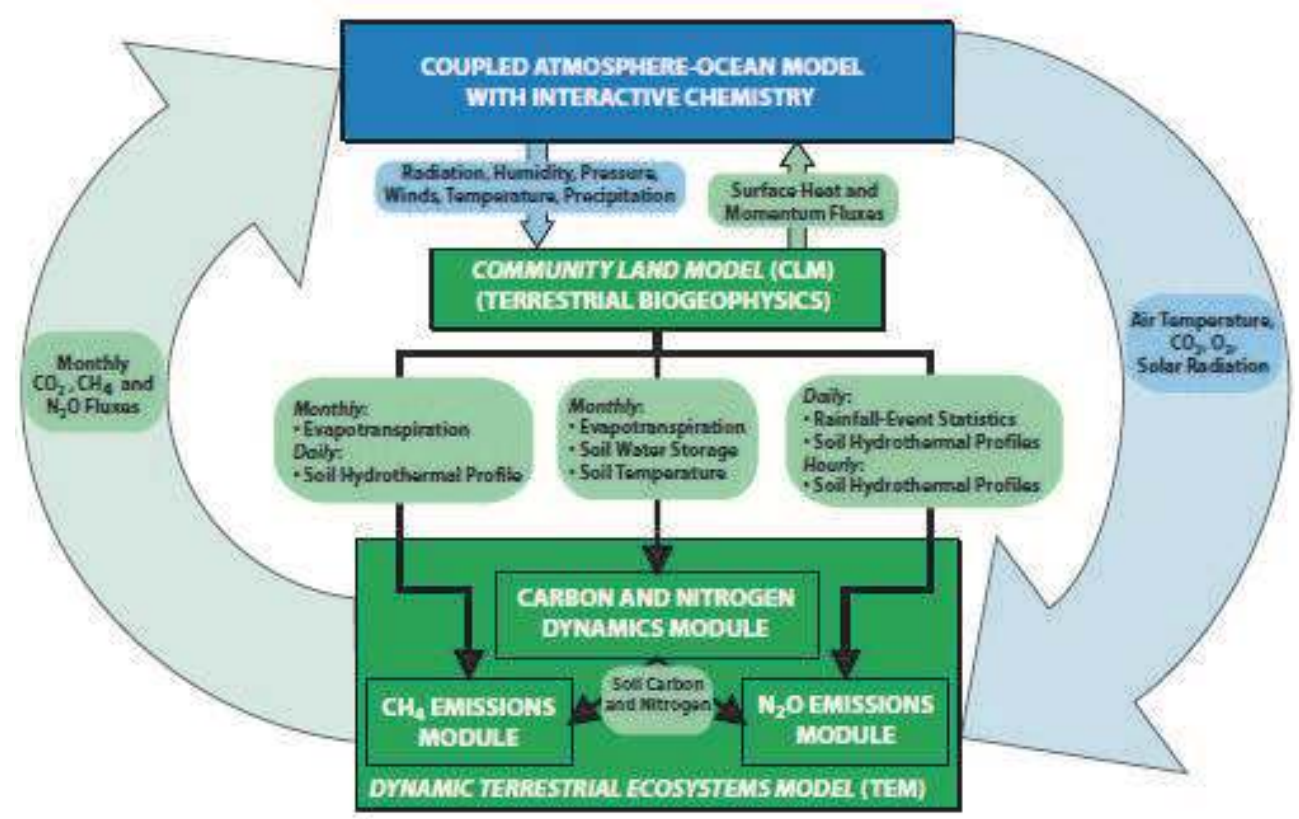

Fig. 9. Schematic of coupling between the atmospheric model (which also includes linkages to the air chemistry and ocean models) and the land model components of the IGSM2, also shown are the linkages between the biogeophysical (CLM) and biogeochemical (TEM) subcomponents. All green shaded boxes indicate fluxes/storage that are explicitly calculated/tracked by this Global Land System (GLS). The blue shaded boxes indicate those quantities that are calculated by the atmospheric model of the IGSM2.

arises from the assumption that emissions are uniformly mixed within the grid cell, and thus do not properly address the initial growth and dispersion of the pollutants.

Lagrangian plume and puff models account for chemical processes by simple linear transformations in time. These models can track individual source impacts, thus enabling user to outline source specific air pollution control strategies. Considerable differences are observed when concentrations are compared in time and space because of uncertainties in the characterization of the direction of transport that are of the order of the actual plume width. The observed and simulated concentrations for fixed receptors, give estimates of maximum concentration values within a factor of two or three of those observed. These differences are an order of magnitude larger than those observed for estimates of secondary pollutants. Both Eulerian and Lagrangian, models are not suitable to handle inert pollutants and secondary pollutants whose concentrations depend on reaction rates and are photochemical in nature.

Receptor models, such as Positive Matrix Factorization and Chemical Mass Balance (CMB), source apportionment addresses the problem by statistical inference of source contributions to total pollution from observations of ambient air chemical composition. Mass balance methods of source apportionment use linear models with chemical composition vectors of sources as covariates. Knowledge of meteorological variables is not required but may be 
used to refine the analysis. Knowledge of emission sources is useful for the interpretation of results from statistical-based receptor models and is required by receptor models that use a mass balance approach. Less data and computational resource requirement by Receptor models as compared to chemical transport models, make them more convenient tool for evaluation of ambient pollutant concentrations and pollutant emission inventory. However, their utility for reactive air pollutants is uncertain and questionable. The disadvantage of CMB model arises from its assumptions. such as constant compositions of source emissions over the period of ambient and source sampling; linear additive and unreactive chemical species; identification of all sources contributing to the receptor and knowledge of their emission profile, linearly independent emission profiles.

The urban air quality models requires

- Good net work ambient air concentrations of pollutants of concern: Geography of the urbanarea, constructed clusters, road network, location of bluidings etc play a major role in dispersion of pollutants. Thus to understand the ambient status of pollutants it is necessary to have sufficient number of monitoring locations to cover the urban sprawl of concern.

- Micro metereology data: The wind patterns, temperature, humidity alter in urban areas according to anthropogenic activity and architecture

- Bluilding details: To account for the effect of anthropogenic architecture falling in path of plume, its geometry is required to be known.

- Knowledge of all sources: All sources and their emission profiles are required to be known to plan for further development in urban area and control of pollutant emission

- Atmospheric Chemistry: All transformations of emitted chemical species, their reaction rates pathways must be known to account for observed concentration of pollutants.

- Healthy Impacts: Models need to incorporate health effect of pollutants

None of the models available can handle all the requirements of urban air quality management. Each one focuses of one aspect and thus coupling of different models are required.

\section{Further issues to be addressed}

COST an intergovernmental framework for European Cooperation in Science and Technology, Europe, addressed issues related to urban air quality models in its action programmes. Cost 728 focussed on enhancing mesoscale meteorological Modeling capabilities for air pollution and Dispersion applications under larger programme of urbanization of meteorological and air quality models. The issues identified for improvements to the state of urbanization of models can be summarized as

- Systematic evaluation of urban land surface schemes

- Increasing the range of variables observed to ensure as complete a range of evaluation as possible

- evaluation over a broad spectrum of conditions (meteorological, morphological, geographical setting, etc.

- Testbeds and observatories with different objectives and dataset richness.

- A deeper understanding of urban PBL dynamics i.e development of long-term urban test beds in a variety of geographic regions (e.g., inland, coastal, complex terrain) and in 
many climate regimes, with a variety of urban core types (e.g., deep versus shallow, homogeneous versus heterogeneous).

- A framework to address conceptual issue of evaluation of model prediction of the flow within the canopy

- User friendly and multifaceted urban databases and enabling technology

- Developing core capabilities for advancing urban modeling and boundary layer research

- An open database to address issues of availability and sources of high-resolution data sets easily to all with mechanism for its maintenance, upgrading, updating, and archiving.

- $\quad$ www.unep.org/urban_environment/pdfs/handbook.pdf

\section{References}

Baklanov, A., and U. Korsholm, 2007: On-line integrated meteorological and chemical transport modelling: advantages and prospective. In: Preprints ITM 2007: 29th NATO/SPS International Technical Meeting on Air Pollution. Modelling and its Application, 24-28.09.2007, University of Aveiro, Portugal, pp. 21-34.

Baklanov, A., Korsholm, U., Mahura, A., Petersen, C., and Gross, A.: ENVIRO-HIRLAM: online coupled modelling of urban meteorology and air pollution, Adv. Sci. Res., pp. 2, 41-46, 2008.

Baklanov A. A. and Nuterman. R. B., Multi-scale atmospheric environment modeling for urban areas, Advances in Science and Research, 3, 53-57, 2009

Bornstein, R., R. Balmori, H. Taha, D. Byun, B. Cheng, J. Nielsen-Gammon, S. Burian, S. Stetson, M. Estes, D.Nowak, and P. Smith, 2006: Modeling the effects of land-use land cover modifications on the urban heat island phenomena in Houston, Texas. SJSU Final Report to Houston Advanced Research Center for Project No. R-04-0055, pp. 127.

Briggs, G. A. (1975). Plume Rise Predictions. Lectures on Air Pollution and Environmental Impact Analysis. D. A. Haugen. Boston, MA, American Meteorology Society: pp.59111.

Carmichael, G.R., and Peters, L.K., 1979, Numerical simulation of the regional transport of $\mathrm{SO}_{2}$ and sulfate in the eastern United States, Proc. 4 th Symp. on turbulence, diffusion and air pollution, AMS 337.

Chen, F., M. Tewari, H. Kusaka and T. L. Warner, 2006: Current status of urban modeling in the community Weather Research and Forecast (WRF) model. Sixth AMS Symposium on the Urban Environment,Atlanta GA, January 2006.

Dupont, S., T.L. Otte, and J.K.S. Ching, 2004: Simulation of meteorological fields within and above urban and rural canopies with a mesoscale model (MM5) Boundary-Layer Meteor., 2004, 113:111-158.

Egan, B.A., Rao, K.S., and Bass, A., 1976, A three dimensional advective-diffusive model for long-range sulfate transport and transformation 7 th ITM, 697, Airlie House.

Friedlander, S.K. (1973). Chemical element balances and identification of air pollution sources, Environmental Science and Technology 7, 235-240

Galmarini, S., J.-F. Vinuesa, and A. Martilli, 2008: Relating small-scale emission and concentration variability in air quality models, Chapter 1.2, URBANIZATION OF 
METEOROLOGICAL AND AIR QUALITY MODELS, COST Action 728, 15 May 2008, http://www.cost728.org

Garratt, J. R. (1978): Transfer Characteristics for a Heterogeneous Surface of Large Aerodynamic Roughness. Quart. J. R. Meteorol. Soc., 104: pp.491-502.

Garratt J.R. (1980) Surface influence upon vertical profiles in the nocturnal boundary layer Boundary-Layer Meteorology Volume 26, Number 1, pp. 69-80, DOI: 10.1007/BF00164331

Garratt J.R. 1994. Review: the atmospheric boundary layer, Earth-Science Reviews, 37, pp.89134.

Gidhagen, L., C. Johansson, J. Langner and G. Olivares. (2004). "Simulation of NOx and ultrafine particles in a street canyon in Stockholm, Sweden." Atmospheric Environment 38(14): 2029-2044.

Gifford Jr., F. A. (1976). "Consequences of Effluent Releases." Nuclear Safety 17(1): 68-86.

Grell, G. A., S. E. Peckham, R. Schmitz, S. A. McKeen, G. Frost, W. C. Skamarock, and B. Eder, 2005: Fully coupled "online" chemistry within the WRF model, Atmos. Environ., 39(37), 6957-6975.

Henry, R.C., 2003. Multivariate receptor modeling by $\mathrm{N}$-dimensional edge detection. Chemometrics and Intelligent Laboratory Systems pp.65, 179-189.

Holmes, N. S., L. Morawska, et al. (2005). "Spatial distribution of submicrometre particles and CO in an urban microscale environment." Atmospheric Environment 39(22): 3977-3988.

Holmes, N. S., Morawska, L. (2006) A review of dispersion modelling and its application to the dispersion of particles: An overview of different dispersion models available. Atmospheric Environment, pp. 40, 5902-5928.

Hopke, P.K. (1985). Receptor Modeling in Environmental Chemistry, Wiley, New York.

Hopke, P.K., ed. (1991). Receptor Modeling for Air Quality Management, Elsevier, Amsterdam.

Hosker, G. L. 1985 Clin. Phys. Physiol. Meas. 6131 A uni-directional urethral force gauge Pavageau, M., Rafailidis, S. and Schatzmann, M. (2001) 'A comprehensive experimental databank for the verification of urban car emission dispersion models', International Journal of Environment and Pollution, 15, pp. 417-425

Jacoby, H.D., Prinn, R.G., Forest, C.E. , Reilly, J., Wang, C., Felzer, B., Sarofim, M.C. , Scott, J., Stone, P.H., Melillo J.M. and Cohen, J., Report No. 124, July 2005

Korsholm, U. S., Baklanov, A., Gross, A., and Sørensen, J. H.: On the importance of the meteorological coupling interval in dispersion modeling during ETEX-1, Atmos. Environ., doi:10.1016/j.atmosenv.2008.11.017, 2008.

Martilli, A., and J.L. Santiago, 2008: How to use computational fluid dynamics models for urban canopy parameterizations. Chapter 2.1, URBANIZATION OF METEOROLOGICAL AND AIR QUALITY MODELS, COST Action 728, 15 May 2008, http://www.cost728.org

Miller, S.L., Anderson, M.J., Daly, E.P., Milford, J.B., 2002. Source apportionment of exposures to volatile organic compounds. I. Evaluation of receptor models using simulated exposure data. Atmospheric Environment pp. 36, 3629-3641.

Mumovic, D., Crowther, J., Stevanovic, Z. (2006). Integrated Air Quality Modelling for a Designated Air Quality Management Area in Glasgow, Building and Environment, 41(12): 1703-1712. doi:10.1016/j.buildenv.2005.07.006

Mumovic, D., Crowther, J. (2006). Assessing Urban Air Quality using Microscale CFD Modeling, PHOENICS CFD Newsletter Spring 2006, 10-10 
Oke, T. R., 1988: "The urban energy balance," Progress in Physical Geography, vol.12, pp. 471508.

Paatero, P., 2004. User's Guide for Positive Matrix Factorization Programs PMF2 and PMF3, Part 1: Tutorial. University of Helsinki, Finland.

Pasquill, F. (1961). "The Estimation of the Dispersion of Windborne Material." Meteorology Magazine 90(1063): pp. 33-40.

Pavageau, M., Rafailidis, S. and Schatzmann, M. (2001) 'A comprehensive experimental databank for the verification of urban car emission dispersion models', International Journal of Environment and Pollution, 15, 417-425

Physick. W.L., Noonan. J.A., MacGregor, J.L. (1994). LADM: a Lagrangian Atmospheric Dispersion Model [Monograph], CSIRO Division of Atmospheric Research technical paper.

Piringer M., Petz E., Groehn I., Schauberger G. (2007) A sensitivity study of separation distances calculated with the Austrian Odour Dispersion Model (AODM), Atmospheric Environment, pp.41, 725-1735.

Raupach, M.R., Thom, A.S., and Edwards, I.: 1980, “A Wind Tunnel Study of Turbulent Flow Close to Regularly Arrayed Rough Surfaces", Boundary-Layer Meteorol. 18, 373-397.

Reynolds, S., Roth, P., and Seinfeld, J., 1973, Mathematical modeling of photochemical air pollution Atm.Env 7.

Rotach, M. W.: 1993.,Turbulence close to a rough urban surface, Part II: Variances and gradients, Boundary Layer Meteorol., pp. 66, 75-92,

Rotach M W (1995) 'Profiles of turbulence statistics in and above an urban street canyon', Atmospheric Environment, Vol 29, pp. 1473-1486

Shir, C.C. and L.J. Shieh, 1974, A generalized urban air pollution model and its application to the study of SO2-distribution in the St. Louis Metropolitan area, J. Appl. Met. 19, 185-204.

2002: South Asia Urban Air Quality Management Briefing. Note No. 4., What Do We Know About Air Pollution? - India Case Study, http:/ / www.worldbank.org/sarurbanair

2002: South Asia Urban Air Quality Management Briefing Note No. 5., Impact of Traffic Management, http://www.worldbank.org/sarurbanair.

Srivastava, Anjali ; Sengupta B., Dutta S.A., 'Source apportionment of ambient VOCs in Delhi City Science of The Total Environment', Volume 343, Issues 1-3, 1 May2005,pp.207-220

Srivastava, Anjali ; 'Source apportionment of ambient VOCS in Mumbai city Atmospheric Environment' , Volume 38, Issuey39, December2004, pp. 6829-6843

Stanners, D., Bourdeau, P. (Eds.), 1995. Europe's Environment: The Dobris Assessment, European Environment Agency.Office for Publications of the European Communities, Luxemburg.

Sokolov, A.P.,C.A. Schlosser, S. Dutkiewicz, S. Paltsev, D.W. Kicklighter, 2005 :The MIT Integrated Global System Model (IGSM),Version 2: Model Description and Baseline Evaluation,

Taha, H., 2008: Sensitivity of the urbanized MM5 (uMM5) to perturbations in surface properties in Houston Texas. Boundary-Layer Meteorology, pp. 127: 193-218

Tennekes, H., 1973. A model for the dynamics of the inversion above a convective boundary layer. Journal of Atmospheric Science 30, pp.550-567 
THOR - an Integrated Air Pollution Forecasting and Scenario Management System. Available at thor.dmu.dk National Environmental Research Institute (NERI), Denmark

Urban Environnent Management, Tool book United Nations Environment Programme, United Nations Human Settlements Programme. Available at www.unep.org/urban_environment/pdfs/handbook.pdf 


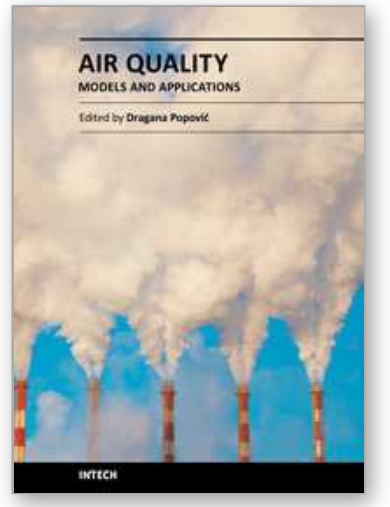

\author{
Air Quality-Models and Applications \\ Edited by Prof. Dragana Popovic
}

ISBN 978-953-307-307-1

Hard cover, 364 pages

Publisher InTech

Published online 09, June, 2011

Published in print edition June, 2011

Air pollution has been a major transboundary problem and a matter of global concern for decades. High concentrations of different air pollutants are particularly harmful to large cities residents, where numerous anthropogenic activities strongly influence the quality of air. Although there are many books on the subject, the one in front of you will hopefully fulfill some of the gaps in the area of air quality monitoring and modeling, and be of help to graduate students, professionals and researchers. The book is divided in five sections, dealing with mathematical models and computing techniques used in air pollution monitoring and forecasting; air pollution models and application; measuring methodologies in air pollution monitoring and control; experimental data on urban air pollution in China, Egypt, Northeastern U.S, Brazil and Romania; and finally, the health effects due to exposure to benzene, and on the influence of air pollutants on the acute respiratory diseases in children in Mexico.

\title{
How to reference
}

In order to correctly reference this scholarly work, feel free to copy and paste the following:

Anjali Srivastava and B. Padma S. Rao (2011). Urban Air Pollution Modeling, Air Quality-Models and Applications, Prof. Dragana Popovic (Ed.), ISBN: 978-953-307-307-1, InTech, Available from: http://www.intechopen.com/books/air-quality-models-and-applications/urban-air-pollution-modeling

\section{INTECH}

open science | open minds

\author{
InTech Europe \\ University Campus STeP Ri \\ Slavka Krautzeka 83/A \\ 51000 Rijeka, Croatia \\ Phone: +385 (51) 770447 \\ Fax: +385 (51) 686166 \\ www.intechopen.com
}

\author{
InTech China \\ Unit 405, Office Block, Hotel Equatorial Shanghai \\ No.65, Yan An Road (West), Shanghai, 200040, China \\ 中国上海市延安西路65号上海国际贵都大饭店办公楼 405 单元 \\ Phone: +86-21-62489820 \\ Fax: +86-21-62489821
}


(C) 2011 The Author(s). Licensee IntechOpen. This chapter is distributed under the terms of the Creative Commons Attribution-NonCommercialShareAlike-3.0 License, which permits use, distribution and reproduction for non-commercial purposes, provided the original is properly cited and derivative works building on this content are distributed under the same license. 